\title{
New Baltic amber soldier beetles (Coleoptera, Cantharidae, Cantharinae)
}

\section{Новые мягкотелки (Coleoptera, Cantharidae, Cantharinae) из балтийского янтаря}

\section{S.V. Kazantsev \\ С.В. Казанцев}

Insect Centre, Donetskaya Str., 13-326, Moscow 109651 Russia. E-mail: kazantss@mail.ru. Инсект-центр, ул. Донецкая, 13-326, Москва 109651 Россия.

Key words: Coleoptera, Cantharidae, Cantharinae, new species, taxonomy, Baltic amber, palaeoentomology, Eocene.

Ключевые слова: Coleoptera, Cantharidae, Cantharinae, новые виды, таксономия, балтийский янтарь, палеоэнтомология, эоцен.

Abstract. Four new species of soldier beetles of the subfamily Cantharinae, Cantharis hanswerneri sp.n., C. hoffeinsorum sp.n., Lycocerus christelae sp.n. and L. dentantennatus sp.n., are described from Baltic amber. Cacomorphocerus Schaufuss, 1892 is tentatively transferred from Dysmorphocerinae to Cantharinae. Provided is a key to the Baltic amber Cantharinae genera.

Резюме. Из балтийского янтаря описывается четыре новых вида мяготелок подсемейства Cantharinae, Cantharis hanswerneri sp.n., C. hoffeinsorum sp.n., Lycocerus christelae sp.n. и L. dentantennatus sp.n. Род Cacomorphocerus Schaufuss, 1892 в предварительном порядке переносится из Dysmorphocerinae в Cantharinae. Предлагается определительная таблица родов подсемейства Cantharinae из балтийского янтаря.

\section{Introduction}

The soldier-beetles subfamily Cantharinae is fairly well represented in Baltic amber, the latter accounting for most of the known amber cantharines. Nine Baltic amber species from seven cantharine genera have been described so far, all during the last fifty years [YablokovKhnzoryan, 1960; Kuśka, 1992; 1996; Kuśka, Kupryjanowicz, 2005; Kuśka, Kania, 2010; Kazantsev, 2013; Poinar, Fanti, 2016; Fanti, 2017]. Three of the genera, Cantharis Linnaeus, 1758, Rhagonycha Eschscholtz, 1830 and Themus Motschulsky, 1858, are extant and four others, Sucinorhagonycha Kuśka, 1996, Sucinocantharis Kuśka et Kania, 2010, Electronycha Kazantsev, 2013 and Michalskantharis Fanti, 2017 are extinct.

The Hoffeins Baltic amber collection in Hamburg, the cantharoid part of which I have had an opportunity to study owing to the courtesy of Christel and Hans Werner Hoffeins, has already yielded several new taxa of Cantharidae [Kuśka, Kania, 2010; Kazantsev, 2013]. A further study of amber inclusions from this collection allows adding several new species from the subfamily Cantharinae, including two from the genus Lycocerus
Gorham, 1889, previously not reported from amber. Descriptions of these new taxa and a note on placement of the genus Cacomorphocerus Schaufuss, 1892, also from Baltic amber, are presented below, as well as a key to the Baltic amber cantharine genera.

Primary types of the Hoffeins collection will be deposited at the Senckenberg Deutsches Entomologisches Institut, Müncheberg, Germany.

\section{Taxonomy}

Cantharis Linnaeus, 1758

Type species Cantharis fusca Linnaeus, 1758.

Remarks. The genus Cantharis Linnaeus, 1758 is widely distributed in the Holarctic, both in the Palaearctic and Nearctic regions, with over three hundred described species [Delkeskamp, 1977; Kazantsev, Brancucci, 2007]. Only two amber species of Cantharis have so far been known, both from Baltic amber: one from the nominative subgenus, the other from the subgenus Cyrtomoptila Motschulsky, 1860 [Kuśka, 1992, 1996; Kazantsev, 2013].

\section{Cantharis (Cantharis) hanswerneri Kazantsev, sp.n. Figs 1-2.}

Material. Holotype, $\mathrm{O}^{7}$, specimen no. 1441-4, Baltic amber, Eocene (Senckenberg Deutsches Entomologisches Institut, Müncheberg, Germany).

Description. $\sigma^{7}$. Dark brown. Head transverse, dorsally flat. Eyes relatively large, bulging. Ultimate maxillary palpomere securiform. Antennae filiform, attaining to elytral two thirds, antennomere 2 ca. 2.5 times shorter than antennomere 3, antennomere 3 ca. 1.1 times shorter than antennomere 4 (Figs 1-2).

Pronotum transverse, with slightly rounded anterior and almost straight posterior margin; pronotal sides rounded; posterior angles blunt; vestiture scarce. Scutellum moderately large, triangular (Figs. 1-2).

Elytra ca. 4.1 times longer than pronotum, parallel-sided, finely and densely punctuate, with uniform, relatively dense semi-erect pubescence (Fig. 1).

Legs with relatively narrow straight femoris and tibiae; tarsomere 4 conspicuously widened, deeply incised; claws 

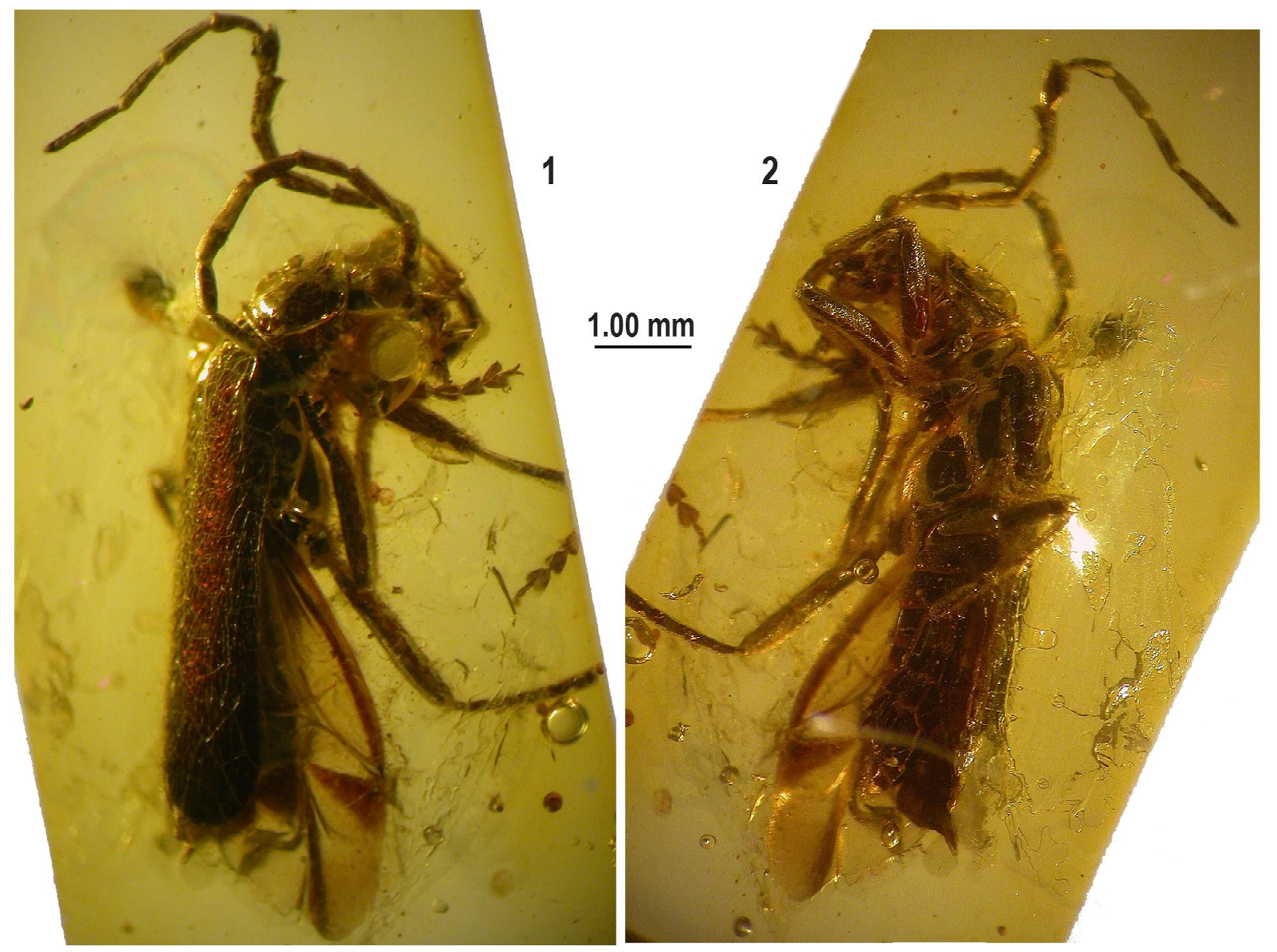

Figs. 1-2. General view of Cantharis hanswerneri sp.n., holotype, $0^{\top}: 1-$ dorso-laterally; 2 - ventro-laterally.

Рис. 1-2. Общий виА Cantharis hanswerneri sp.n., голотип, о : 1 - сверху и сбоку; 2 - снизу и сбоку.

simple. Abdomen with eight ventrites, penultimate ventrite roundly incised, ultimate ventrite triangular, relatively broad (Figs. 1-2).

Length (from anterior head margin to end of elytra): 6.5 $\mathrm{mm}$. Width (humerally): $1.5 \mathrm{~mm}$

\section{+. Unknown.}

Syninclusions. None.

Etymology. The new species is named after Hans Werner Hoffeins (Hamburg) who kindly provided a possibility to study Baltic amber beetle specimens from his and Ms Hoffeins' collection.

Diagnosis. Cantharis hanswerneri sp.n., may be distinguished from C. sucinonigra Kuśka, 1992, the only other amber Cantharis s. str. known to this date, by the dark brown pronotum, relatively long elytra and relatively short antennomere 2 , which is ca. 2.5 times shorter than antennomere 3 (Figs. 1-2).

\section{Cantharis (Cantharis) hoffeinsorum Kazantsev, sp.n. \\ Figs. 3-5.}

Material. Holotype, $O^{7}$, specimen no. 1593-2, Baltic amber, Eocene (Senckenberg Deutsches Entomologisches Institut, Müncheberg, Germany).

Description. $\sigma^{7}$. Dark brown; pronotal margins narrowly lighter. Head transverse, dorsally flat, shining, with scarce short pubescence. Eyes relatively large, bulging. Ultimate maxillary palpomere securiform. Antennae almost attaining to elytral apices, antennomere 2 ca. 1.3 times shorter than antennomere 3, antennomere 3 ca. 1.2 times shorter than antennomere 4; antennomeres 3-9 dentate (Figs. 3-5).

Pronotum transverse, about 1.5 times wider than long, with almost straight anterior and conspicuously convex posterior margin, noticeably incised near posterior angles; pronotal sides rounded; posterior angles blunt; vestiture relatively scarce, semi-erect. Scutellum relatively large, transverse, triangular, concave at sides, with moderately dense short semierect vestiture (Fig. 3).

Elytra ca. 3.1 times longer than pronotum and ca. 1.9 times longer than wide at humeri, parallel-sided, finely and densely punctuate, with uniform sparse semi-erect pubescence (Fig. 3).

Legs with relatively narrow straight femoris and tibiae; tarsomere 4 conspicuously widened, deeply incised; claws simple. Abdomen with eight ventrites, penultimate ventrite roundly incised, ultimate ventrite triangular, relatively broad (Figs. 3-5).

Length (from anterior head margin to end of elytra): 3.3 $\mathrm{mm}$. Width (humerally): $1.2 \mathrm{~mm}$.

†. Unknown.

Syninclusions. None.

Etymology. The new species is named after Christel and Hans Werner Hoffeins (Hamburg) who kindly provided a possibility to study Baltic amber beetle specimens from their collection.

Diagnosis. Cantharis hoffeinsorum sp.n. may be distinguished from C. hanswerneri sp.n. and C. sucinonigra by the smaller size, wider pronotum and noticeably dentate antennomeres 3-9 (Figs. 3-5). 


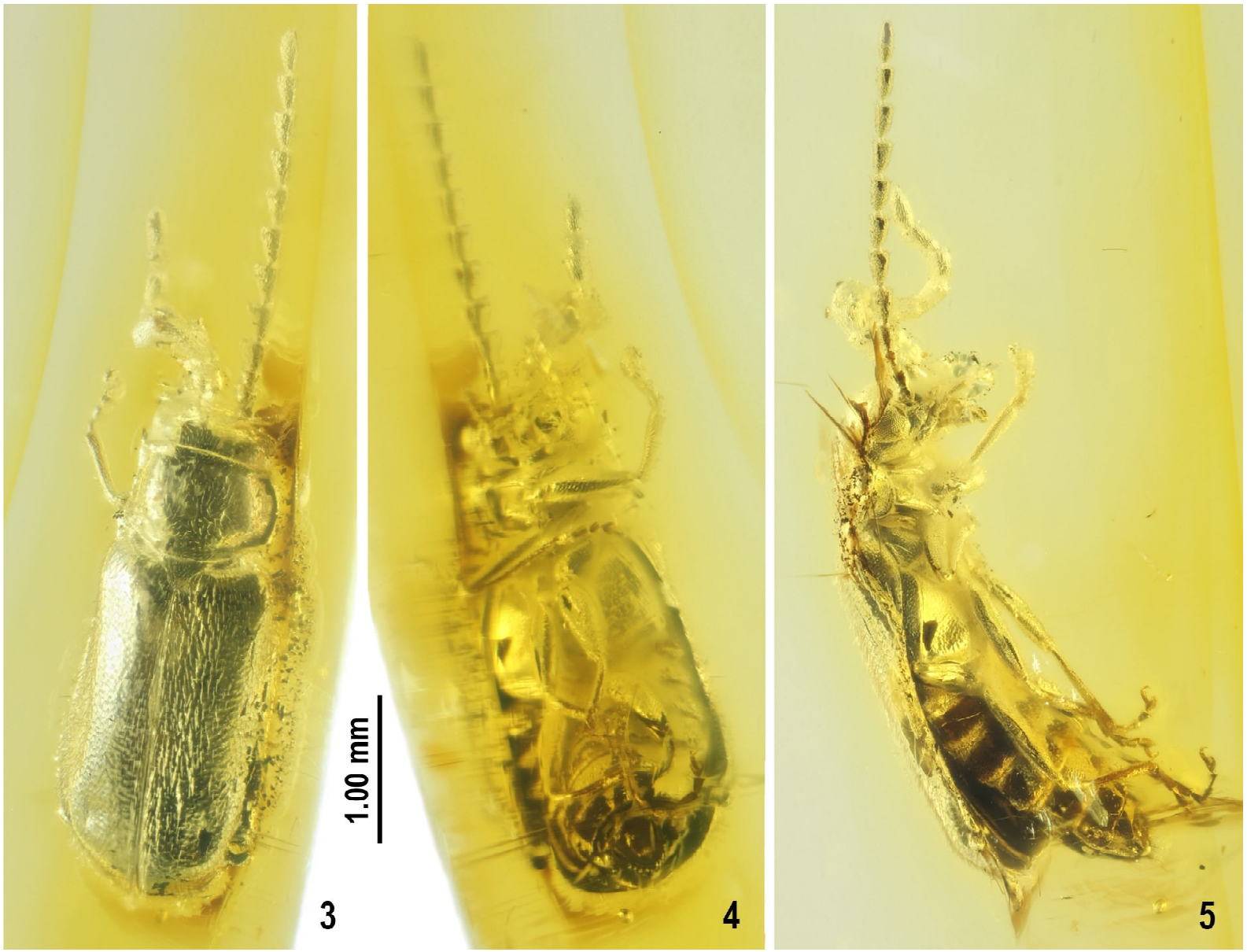

Figs 3-5. General view of Cantharis hoffeinsorum sp.n., holotype, $0^{7}: 3$ - dorsally; 4 - ventrally; 5 - laterally. Рис. 3-5. Общий вид Cantharis hoffeinsorum sp.n., голотип, о?: $3-$ сверху; $4-$ снизу; $5-$ сбоку.

\section{Lycocerus Gorham, 1889}

Type species Lycocerus serricornis Gorham, 1889.

Remarks. The genus Lycocerus Gorham, 1889 accounts for several hundred species distributed in the south-eastern Palaearctic and Oriental regions [Delkeskamp, 1977; Okushima, 2005; Kazantsev, Brancucci, 2007]. The genus is similar to Cantharis, differing by the paired dorsal blades of the aedeagus, as well as by the mostly elongate trapezoidal pronotum with more or less concave sides [Okushima, 2005]. At the same time it has certain affinities with Podistra Motschulsky, 1839, but is reliably differentiated by the pronotal shape, as well as the structure of the aedeagus. As the study of male genital structures is impeded by the fossil nature of inclusions, it is the difference in the shape of pronotum that was taken into account to attribute specimens to genus. It is the first time that a species of Lycocerus has been reported from Baltic amber.

\section{Lycocerus christelae Kazantsev, sp.n.}

Figs 6-8.

Material. Holotype, $\sigma^{\top}$, specimen no. 1441-3, Baltic amber, Eocene (Senckenberg Deutsches Entomologisches Institut, Müncheberg, Germany).

Description. $\sigma^{7}$. Dark brown; pronotal margins narrowly lighter. Head transverse, dorsally flat, densely punctuate, with short pubescence. Eyes relatively large, bulging. Ultimate maxillary palpomere elongate, securiform. Antennae filiform, attaining to elytral apices, antennomere 2 ca. 2 times shorter than antennomere 3 , antennomere 3 ca. 1.5 times shorter than antennomere 4 (Figs. 6-7).

Pronotum elongate, with convex anterior and almost straight posterior margin; pronotal sides slightly concave; posterior angles almost rectangular; vestiture relatively scarce, semi-erect. Scutellum relatively small, triangular, concave at sides (Figs. 6-7).

Elytra long, ca. 4.8 times longer than pronotum and ca. 3.4 times longer than wide at humeri, parallel-sided, finely and densely punctuate, with uniform sparse erect pubescence (Fig. 6).

Legs with narrow straight femoris and tibiae; tibiae with evident spurs; tarsomere 4 conspicuously widened, deeply incised; claws simple. Abdomen with eight ventrites, penultimate ventrite roundly incised, ultimate ventrite triangular, relatively broad (Figs. 6-8).

Length (from anterior head margin to end of elytra): 4.4 $\mathrm{mm}$. Width (humerally): $0.8 \mathrm{~mm}$.

+. Unknown.

Syninclusions. None.

Etymology. The new species is named after Christel Hoffeins (Hamburg) who kindly provided a possibility to study Baltic amber beetle specimens from her and Mr Hoffeins' collection.

Diagnosis. Lycocerus christelae sp.n. is readily distinguished from $L$. dentantennatus sp.n., the only other fossil member of the genus, by the filiform antennae (Figs. 6-7). 


\section{Lycocerus dentantennatus Kazantsev, sp.n. \\ Figs 9-11.}

Material. Holotype, $O^{7}$, specimen no. 1593-3, Baltic amber, Eocene (Senckenberg Deutsches Entomologisches Institut, Müncheberg, Germany)

Description. $\sigma^{7}$. Dark brown; head yellowish; legs lighter brown. Head transverse, ca. 2 times wider than long, dorsally flat, glabrous. Eyes relatively large, bulging, interocular distance ca. 4 times greater than eye radius. Ultimate maxillary palpomere elongate, securiform. Antennae robust, attaining to elytral two thirds, antennomere 2 ca. 2.5 times shorter than antennomere 3 , antennomere $3 \mathrm{ca} .1 .4$ times shorter than antennomere 4; antennomeres 3-9 conspicuously dentate (Figs. 9-11).

Pronotum about as long as wide, conspicuously bulged medially, with convex anterior margin and noticeably concave pronotal sides; posterior angles almost rectangular; vestiture relatively scarce, semi-erect. Scutellum relatively small, triangular (Figs. 9-11).

Elytra parallel-sided (their apices missing), with uniform dense short erect pubescence (Figs. 9-10).

Legs with relatively robust straight femoris and narrow straight tibiae; tibial spurs evident; tarsomere 4 conspicuously widened, deeply incised; claws simple. Abdomen with eight ventrites, penultimate ventrite roundly incised, ultimate ventrite triangular, relatively broad (Figs. 9-10).

Length (from anterior head margin to end of elytra): 6.8 mm. Width (humerally): $1.7 \mathrm{~mm}$.

+. Unknown.

Syninclusions. Head of a Hemiptera.
Etymology. The name of the new species is derived from the Latin for "with dentate antennae", alluding to its antennal structure.

Diagnosis. Lycocerus dentantennatus sp.n., may be easily distinguished from $L$. christelae sp.n., the only other fossil member of the genus, by the conspicuously dentate antennae (Figs. 9-10).

\section{Cacomorphocerus Schaufuss, 1892}

Type species Cacomorphocerus cerambyx Schaufuss, 1892.

Remarks. None of the characters that actually separate the subfamily Dysmorphocerinae from other cantharids, i.e., the structure of tentorium, wing venation, structure of male and female genitalia [Brancucci, 1980], have ever been studied in amber soldier beetles, including the genus Cacomorphocerus Schaufuss, 1892. Cacomorphocerus was placed near Dysmorphocerus Solier, 1849 [Schaufuss, 1892] and later referred to Dysmorphocerinae [e.g., Kazantsev, 2013; Alekseev, 2013] solely on the basis of the number of its antennomeres, which exceeds eleven, and modified middle antennomeres, which is reported in some dismorphocerines [e.g., Brancucci, 1980], at a time when the structure and number of antennomeres are not used for higher level classification in the family, on the one hand, and conspicuously modified antennomeres are more widespread in Silinae and Malthininae [e.g., Brancucci, 1980], on the other. The other Baltic amber cantharid genera with 12 17 segmented antennae (Sucinorhagonycha Kuśka, 1996, Sucinocantharis Kuśka et Kania, 2010, Electronycha Kazantsev, 2013 and Michalskantharis Fanti, 2017) seem to be typical cantharines and are considered cantharine taxa [Alekseev, 2013; Kazantsev, 2013; Fanti, 2017]. In this respect it appears
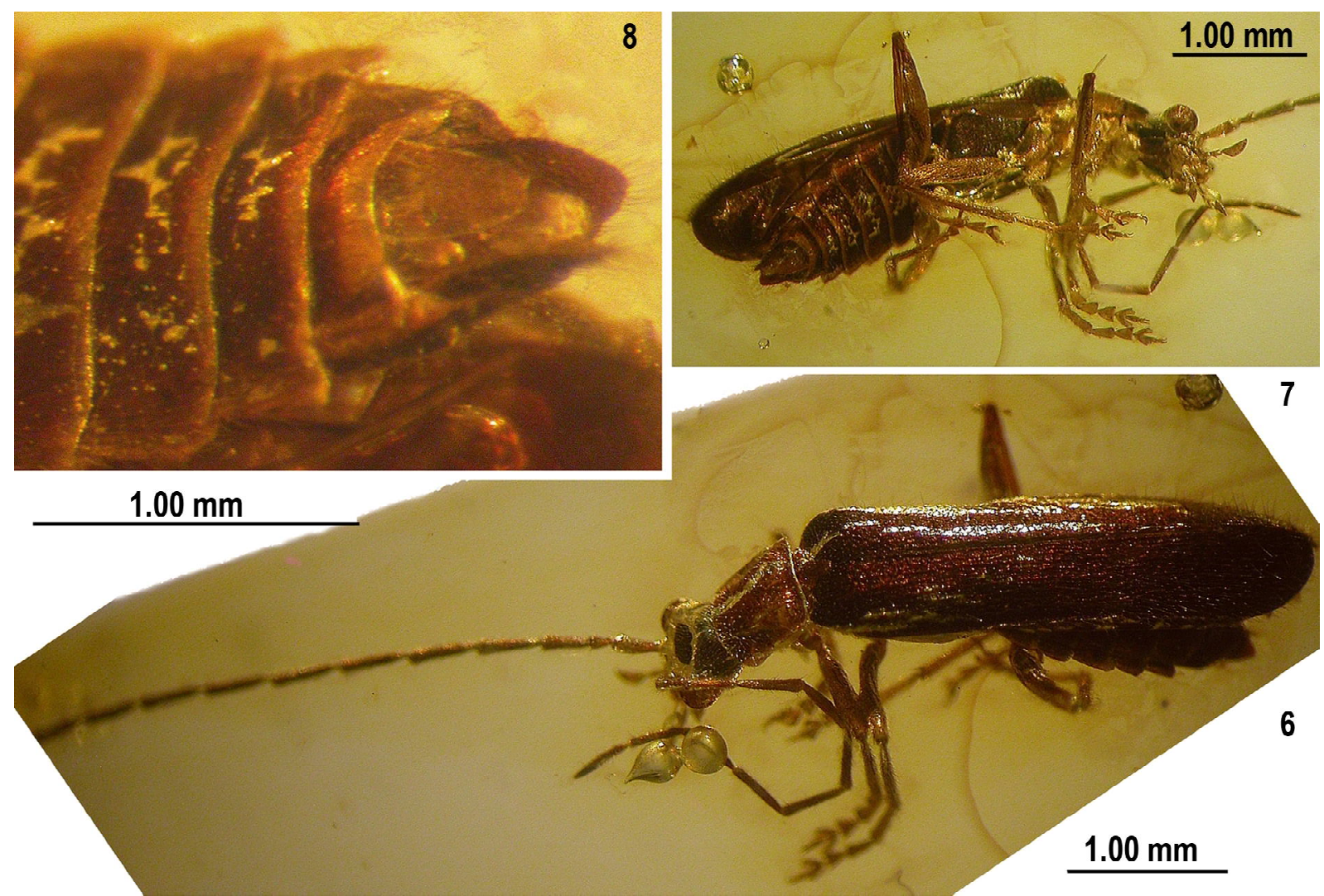

Figs. 6-8. Lycocerus christelae sp.n., holotype $0^{7}: 6$ - general view, dorso-laterally; 7 - same, ventro-laterally; 8 - apex of abdomen, ventro-laterally.

Рис. 6-8. Lycocerus christelae sp.n., голотип о : 6 - общий виА, сверху и сбоку; 7 - то же, снизу и сбоку; 8 - вершина брюшка, снизу и сбоку. 

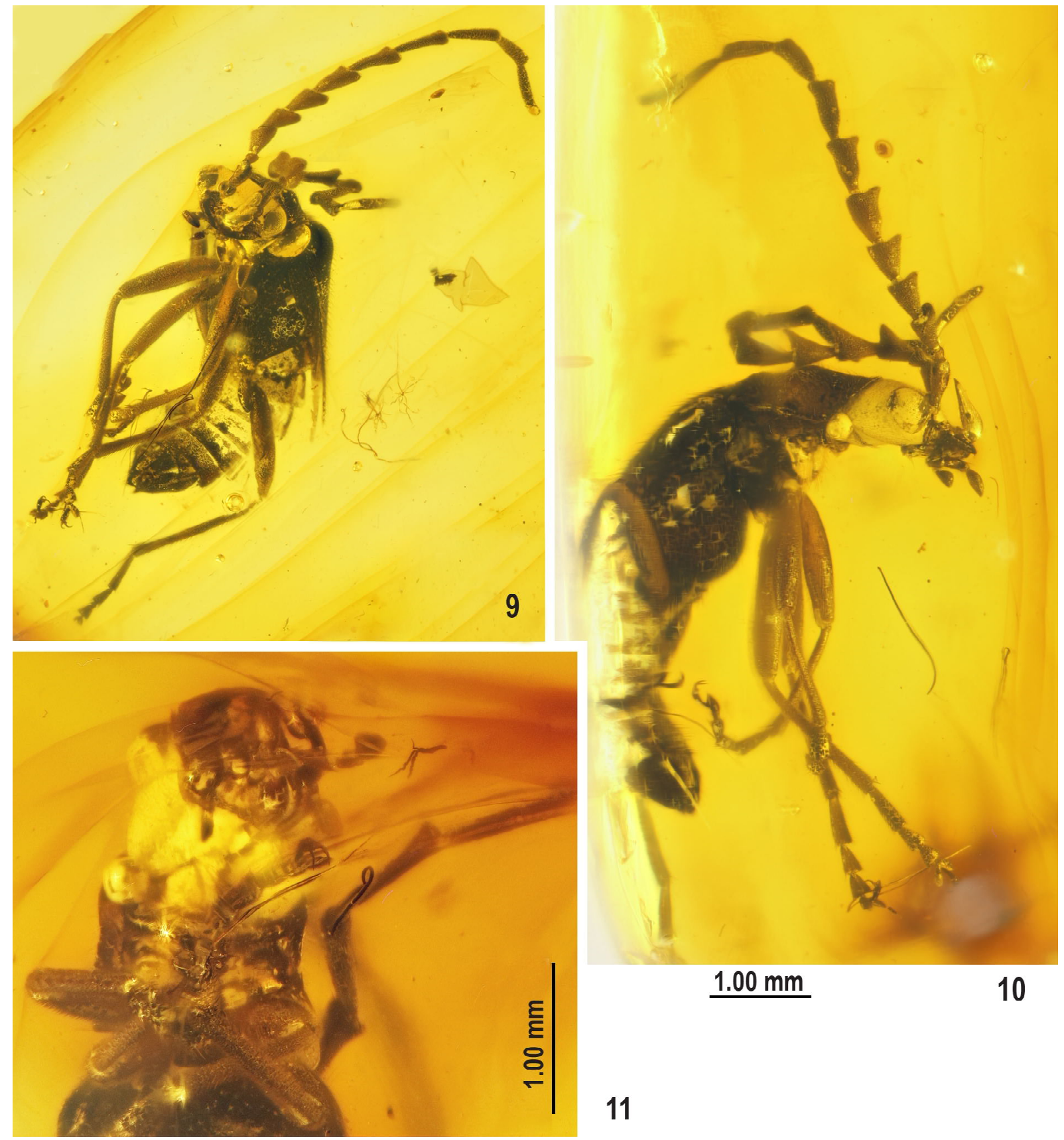

Figs. 9-11. Lycocerus dentantennatus sp.n., holotype $0^{7}: 9-$ general view, ventrally; 10 - same, laterally; $11-$ head and pronotum, ventrally.

Рис. 9-11. Lycocerus dentantennatus sp.n., голотип О': 9 - общий вид, снизу; 10 - то же, сбоку; $11-$ голова и переднеспинка, снизу.

plausible to transfer Cacomorphocerus to Cantharinae as well, pending further studies that could bring light to its inner structures, possibly with the use of synchrotron X-ray microtomography.

\section{Cacomorphocerus jantaricus}

(Kuśka et Kania, 2010)

Figs $12-14$.

Hoffeinsensia jantarica Kuśka et Kania, 2010: 50

Material. $\sigma^{7}$, specimen no. 771-2, Baltic amber, Eocene (Hoffeins collection).

\section{Key to the Baltic amber genera of Cantharinae}

1. Antennae 11-segmented 2

Antennae with more than 11 segments ...meng 6

2. Claws bifid .......................... Rhagonycha Eschscholtz

- Claws simple, at most with basal denticles ................. 3

3. Cheeks longer than eye radius. Pronotum transverse, rectangular, flattened ................. Them us Motschulsky

- Cheeks shorter than eye radius. Pronotum convex, often elongate and rounded 
4. Pronotum often elongate, concave at sides

Lycocerus Gorham

- Pronotum often transverse, straight or rounded at sides (Cantharis Linnaeus).

5. Pronotum often rounded at sides. $\sigma^{7}$ outer claw with basal denticle Cantharis (Cantharis) Linnaeus

- Pronotum often straight at sides. $\sigma^{\gamma}$ claws simple ......... Cantharis (Cyrtomoptila) Motschulsky

6. Antennae 17-segmented, middle antennomeres inflated Michalskantharis Fanti

- Antennae with less than 17 segments

7. Antennae 16-segmented, middle antennomeres conspicuously modified Sucinocantharis Kuśka

- Antennae with less than 16 segments

8. Antennae 15-segmented, with distally swollen antennomeres 6-9 Electronycha Kazantsev

- Antennae 12-segmented

9. Antennomeres unmodified and filiform Sucinorhagonycha Kuśka

- Antennomeres 3-9 conspicuously modified Cacomorphocerus Schaufuss

\section{Discussion}

The occurrence in Baltic amber of the genus Lycocerus Gorham, 1889, whose extant members are distributed in the south-eastern Palaearctic and Oriental regions [Delkeskamp, 1977; Okushima, 2005; Kazantsev, Brancucci, 2007] is not surprising. There is another genus in the subfamily, Themus, with a similar distribution pattern. At present it is known only from the southeastern Palaearctic and Oriental regions [Kazantsev, Brancucci, 2007], and its only fossil species was found in Baltic amber [Kazantsev, 2013]. At the same time the other Baltic amber cantharine genera are either entirely fossil, namely Sucinorhagonycha, Sucinocantharis, Electronycha and Michalskantharis, or have extant species distributed from the Atlantic to the Pacific coasts and further on in the Nearctic region, Cantharis and Rhagonycha [Delkeskamp, 1977; Kazantsev, Brancucci, 2007].

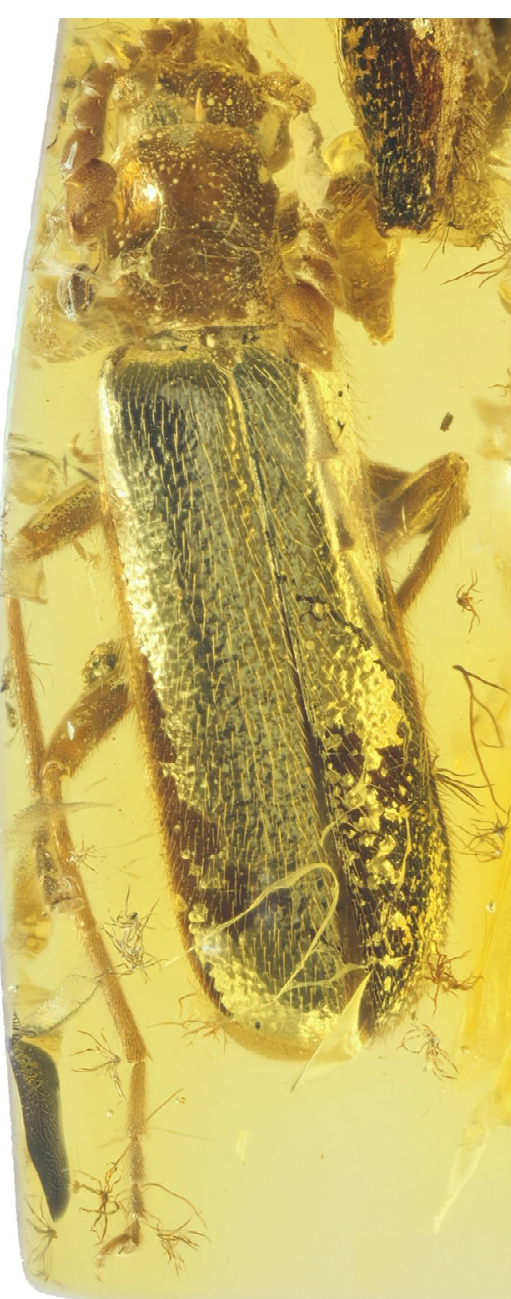

12
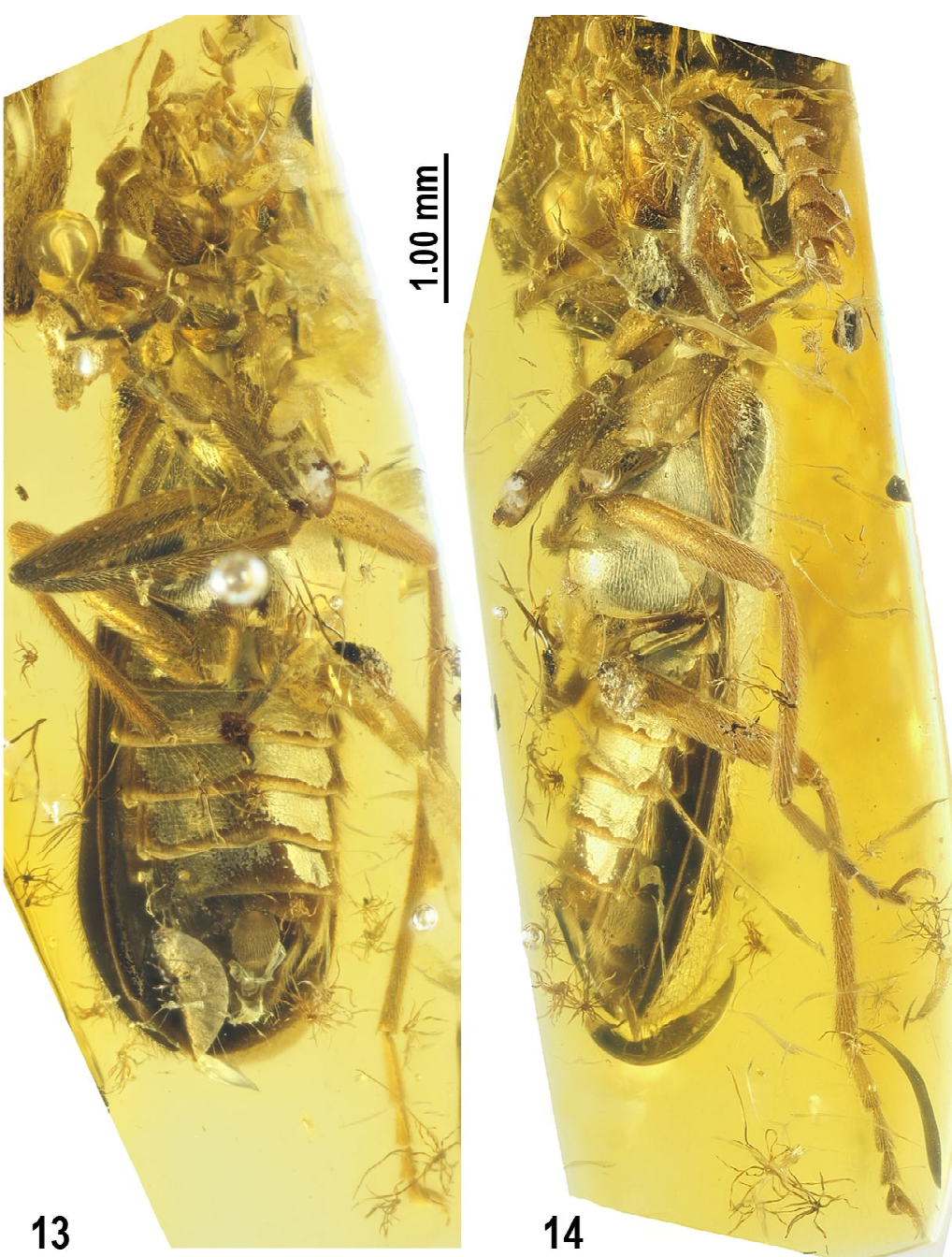

Figs. 12-14. General view of Cacomorphocerus jantaricus, ơ: 12 - dorsally; 13 - ventrally; 14 - laterally. Рис. 12-14. Общий вид Сасотоrphocerus jantaricus, о?: 12 - сверху; $13-$ снизу; $14-$ сбоку. 


\section{Acknowledgements}

It is my pleasant duty to express gratitude to Christel and Hans Werner Hoffeins (Hamburg) for the possibility to study Baltic amber beetle specimens from their collection. My thanks are also due to Prof. K.V. Makarov (Moscow) for his help with the photos of the new taxa.

\section{References}

Alekseev V.I. 2013. The beetles (Insecta: Coleoptera) of Baltic amber: the checklist of described species and preliminary analysis of biodiversity // Zoology and Ecology. Vol.23. No.1. P.5-12.

Brancucci M. 1980. Morphologie comparée, évolution et systématique des Cantharidae (Insecta: Coleoptera) // Entomologica Basiliensia. Vol.5. P.215-388.

Delkeskamp K. 1977. Coleopterorum Catalogus Supplementa. Pars 165. Fasc.1. Editio secunda. Cantharidae. The Hague: W. Junk Publishers. P.1-485.

Fanti F. 2017. New fossil Cantharidae genus and species from Baltic amber (Insecta Coleoptera) // Giornale Italiano di Entomologia. Vol.14. P.709-714.

Kazantsev S.V. 2013. New taxa of Baltic amber soldier beetles (Insecta: Coleoptera: Cantharidae) with synonymic and taxonomic notes // Russian Entomological Journal. Vol.22. No.4. P.283-293.
Kazantsev S.V., Brancucci M. 2007. Cantharidae. P. 234-298. // Löbl I., Smetana A. (Eds).: Catalogue of Palaearctic Coleoptera. Vol.4. Stenstrup: Apollo Books. P.1-935.

Kuśka A. 1992. Three new species of beetles (Coleoptera: Cantharidae, Anobiidae, Curculionidae) from the Baltic Amber // Annals of the Upper Silesian Museum - Entomology. Vol.3. P.107-113.

Kuśka A. 1996. New beetle species (Coleoptera, Cantharidae, Curculionidae) from the Baltic amber // Prace Muzeum Ziemi. Vol.44. P.13-18.

Kuśka A., Kupryjanowicz J. 2005. Soldier beetles (Coleoptera, Cantharidae) from Baltic amber // Polskie Pismo Entomologiczne. Vol.74. P.309-316.

Kuśka A., Kania I. 2010. New soldier beetles (Coleoptera, Cantharidae) from the Eocene Baltic amber // Zootaxa. Vol.2400. P.49-56.

Poinar G.O., Jr., Fanti F. 2016. New fossil soldier beetles (Coleoptera: Cantharidae) in Burmese, Baltic and Dominican amber // Palaeodiversity. Vol.9. P.1-7.

Okushima Y. 2005. A taxonomic study on the genus Lycocerus (Coleoptera, Cantharidae) from Japan, with zoogeographical considerations // Japanese Journal of Systematic Entomology (Monographic Series). Vol.2. P.1-383.

Schaufuss C. 1892. Preussens Bernstein-Käfer. I. Neue Formen aus der Helm'schen Sammlung im Danziger Provinzialmuseum // Berliner Entomologische Zeitschrift (1891). Vol.36. No.1. P.53-64.

Yablokov-Khnzoryan S.M. 1960. New beetles from the Baltic amber // Paleontologicheskij Zhurnal. Vol.3. P.90-101. [In Russian]. 